MEDICAL MEMORANDA

\section{Gas-filled Joints after Oxy-Helium Saturation Dive}

\author{
R. de G. HANSON, J. VOROSMARTI, \\ J. A. B. HARRISON
}

British Medical fournal, 1974, 3, 154

Though gas may be detected radiographically in joints this is considered to be a chance finding. Gas in joints after decompression fnom hyperbaric pressures has been reported in animals (Gersh, 1946) but so far as we have been able to ascertain this has never before been noted in association with a particular dive in divers with or without symptoms of decompression sickness. It has been recognized for some time that symptomless gas-filled joints (aeroarthrosis) may result from decompression to subatmospheric pressure (Fulton, 1951; Fryer and Roxburgh, 1965).

Dives to more than $200 \mathrm{ft}$. $(60 \mathrm{~m})$ are made with oxygen and helium since at these depths the nitrogen in air is unmanageable. The following case appears to be the first to be reported in which gas in a joint was detected after a specific dive schedule, using oxygen and helium saturation.

\section{Case Report}

The dive, using a chamber, was to $590 \mathrm{ft}(180 \mathrm{~m})$ for a bottom time of 23 hours and was carried out at the Deep Trials Unit, Alverstoke. The decompression schedule used was that calculated by Bornmann (1967) and was based on a tissue half time of 240 minutes. (This decompression gave the following rates of ascent: 590 to $200 \mathrm{ft}$ at $6 \mathrm{ft} / \mathrm{hr}, 200$ to $100 \mathrm{ft}$ at $5 \mathrm{ft} / \mathrm{hr}, 100$ to $50 \mathrm{ft}$ at $4 \mathrm{ft} / \mathrm{hr}$, and $50 \mathrm{ft}$ to surface $3 \mathrm{ft} / \mathrm{hr}$.) Conditions inside the chamber were maintained as follows; $\mathrm{Po}_{2} 0.3 \pm 0.02$ bar $(228 \mathrm{~mm}$ $\mathrm{Hg}$ ), Pco: 0.005 bar $\left(3.8 \mathrm{~mm} \mathrm{Hg}\right.$ ), air temperature $28.5-30.0^{\circ} \mathrm{C}$, water temperature $20^{\circ} \mathrm{C}$, relative humidity approximately $70 \%$. Diving was carried out during the bottom time but no exercises apart from mild calisthenics were done during the decompression phase. The decompression schedule consisted of periods of eight hours of decompression followed by alternating rest periods of two to six hours. The total dive time was 203 hours, of which 177 hours was spent decompressing.

The subject of this report, one of three divers, was an experienced Royal Naval clearance diver. He had not made any saturation dives previously. He was aged 24 and his height and weight were $178 \mathrm{~cm}$ and $94 \mathrm{~kg}$ respectively. The dive was uneventful apart from one of the other divers reporting a fleeting joint pain, or niggle, on arriving at $254 \mathrm{ft}(77.5 \mathrm{~m})$. On arrival at the surface the divers reported that they felt well. At the medical examination after the dive the subject reported that he had felt a "slight something" in his knees during the last $13 \mathrm{ft}(4 \mathrm{~m})$ of ascent. These vague feelings of "something moving" are not uncommon during decompression from long and deep dives and are not symptomatic of decompression sickness. Both knees made an audible "squelch" when moved passively and there was crepitus

\footnotetext{
Royal Naval Physiological Laboratory, Alverstoke, Hants PO12 2DU

R. DE G. HANSON, M.D. B.ch., B.A.O., Surgeon Commander, Royal Navy J. VOROSMARTI, M.D., Commander United States Navy Medical Corps J. A. B. HARRISON, M.R.C.S., L.R.C.P., D.M.R.D., Surgeon Captain, Royal Navy
}

over the suprapatellar bursae and over the lower parts of the vasti laterales. The subject felt no discomfort. $X$-ray examinaticn showed both knee joints to be filled with gas, which had tracked up the fascial planes. Over the next two days the gas was reabsorbed and the joints returned to normal.

\section{Comment}

Normally dives are of relatively short duration and the gases in the tissues do not have time to equilibrate with the ambient pressure. When diving to beyond $300 \mathrm{ft}$. $(90 \mathrm{~m})$ the decompression required for all but the shortest dives becomes an extremely lengthy procedure. For instance, a dive using oxygen and helium to give a 15-minute bottom time at 300 $\mathrm{ft}$. requires a total dive time of about 1 hour 33 minutes, while at $500 \mathrm{ft}$. $(152 \mathrm{~m}) 5$ hours 37 minutes is required to achieve the same bottom time. Bottom time is the time from leaving surface to leaving bottom; the time spent actually working is much less.

If a diver remains at pressure long enough the gases dissolved in his tissues equilibrate with those in the ambient atmosphere and he will require the same decompression period regardless of the time spent at maximum pressure. For work requiring anything but the shortest stay at these pressures it is better for the divers to live under pressure until the job is completed, when they can undergo a single decompression. This type of diving, known as saturation diving, is a recent concept. The position of divers decompressing from a saturation dive is analogous to that of a person saturated at 1 atmosphere in a $22 / 78 \%$ oxygen/nitrogen environment who is leaving the earth's surface in an unpressurized aircraft. In the case of the diver the pressures are far greater, so that it is not surprising that a phenomenon which has previously been reported in aviators should be found in this type of diving.

Though the gas present in the joints was not analysed most was likely to be helium, as the divers had been living in an oxygen-helium environment for over eight days. It may be that this finding of helium or other inert gas in joints is common and has not been noticed before. This would not be surprising as it is not customary to subject divers to an $x$-ray examination after an uneventful dive, and if they have developed decompression sickness it is important to return them to pressure as soon as possible. If sufferers from joint pain decompression sickness were to undergo $x$-ray examination before treatment gas might be seen in and around the affected joint. This has already been done in a number of subjects decompressed to $35,000 \mathrm{ft}$. (10,650 m; Fulton, 1951) and it was evident that there was a high correlation between pain and the presence of periarticular extravascular streaks and bubbles but not between pain and gas in the knee joint. Such an investigation, however, should not be undertaken if it delays treatment. With regard to the saturation diver we are at present carrying out a survey to see whether this chance finding can be repeated.

We thank the Controller of H.M.S.O. for permission to report these findings.

\section{References}

Bornmann, R. C. (1967). In Proceedings of Third Symposium on Urderwater Physiology, ed. C. J. Lambertsen. Baltimore, Williams and Wilkins.

Fryer, D. I., and Roxburgh, H. L. (1965). In Textbook of Aviation Medicine, ed. J. A. Gillies, p. 127. Glasgow, Blackie and Son.

Fulton, J. F. (1951). Decompression Sickness, p. 31. Philadelphia, Saunders. Gulton, J. F. (1946). Fournal of Cellular and Comparative Physiology, 28, 271. 